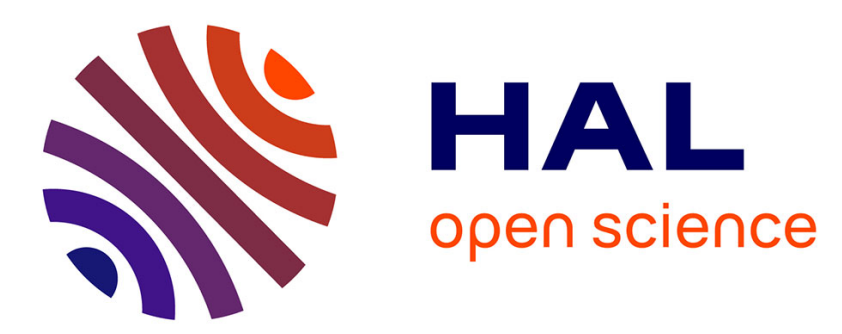

\title{
From Milk and Wool: Vital Pastoral Crafts and their Vitality in 21 st Century Xinjiang
}

\author{
Annie Chan
}

\section{To cite this version:}

Annie Chan. From Milk and Wool: Vital Pastoral Crafts and their Vitality in 21 st Century Xinjiang. Journal of Ethnobiology and Ethnomedicine, 2017, 37 (3), pp.542-560. 10.2993/0278-0771-37.3.542 . hal-03111597

\section{HAL Id: hal-03111597 https://hal.science/hal-03111597}

Submitted on 15 Jan 2021

HAL is a multi-disciplinary open access archive for the deposit and dissemination of scientific research documents, whether they are published or not. The documents may come from teaching and research institutions in France or abroad, or from public or private research centers.
L'archive ouverte pluridisciplinaire HAL, est destinée au dépôt et à la diffusion de documents scientifiques de niveau recherche, publiés ou non, émanant des établissements d'enseignement et de recherche français ou étrangers, des laboratoires publics ou privés. 


\section{From Milk and Wool: Vital Pastoral Crafts and their Vitality in $21^{\text {st }}$ Century Xinjiang}

Author(s): Annie Chan

Source: Journal of Ethnobiology, 37(3):542-560.

Published By: Society of Ethnobiology

https://doi.org/10.2993/0278-0771-37.3.542

URL: http://www.bioone.org/doi/full/10.2993/0278-0771-37.3.542

BioOne (www.bioone.org) is a nonprofit, online aggregation of core research in the biological, ecological, and environmental sciences. BioOne provides a sustainable online platform for over 170 journals and books published by nonprofit societies, associations, museums, institutions, and presses.

Your use of this PDF, the BioOne Web site, and all posted and associated content indicates your acceptance of BioOne's Terms of Use, available at www.bioone.org/page/ terms of use.

Usage of BioOne content is strictly limited to personal, educational, and noncommercial use. Commercial inquiries or rights and permissions requests should be directed to the individual publisher as copyright holder. 


\title{
FROM MILK AND WOOL: VITAL PASTORAL CRAFTS AND THEIR VITALITY IN $21^{\text {ST }}$ CENTURY XINJIANG
}

\author{
Annie Chan $^{1}$
}

\begin{abstract}
Ecological and socioeconomic effects of sedentarization campaigns and growing state controls on pastoral practices are a prevalent topic of interest in the study of nomads. Research to date has focused on how processes of industrialization and urbanization bear on the productivity of pasturage and livestock; other constituents of pastoral livelihood, such as secondary animal products, remain less explored. In documenting the making of felt and milk products by Kazakh and Mongol practitioners in the Bortala Mongol Autonomous Prefecture, this paper explores the perpetuation of pastoral crafts amid household modernization and the building of market economy in the Xinjiang Uyghur Autonomous Region in western China. The tradition of domestic production of milk products continues despite increased state-control on pastoral ways of life. In contrast, felt-making is no longer essential to domestic subsistence but survives as a handicraft known to selected members of the community and a token of ethnic heritage. This study proposes that these traditional pastoral crafts should not be valued simply as records of the historic past. Instead, they provide essential knowledge for designing more sustainable measures in current state reforms.
\end{abstract}

Keywords: pastoralism, sedentarization, felt, milk products, cultural heritage

\section{Introduction}

It is not unexpected that in China, one of the world's fastest growing economies, preserving artisanal skills of production would be peripheral to state goals of industrialization and modernization. Reforms targeting the western regions, for instance, stem from an explicit agenda to lessen the economic disparity between coastal China and interior provinces, consolidate political control over an ethnically diverse population, and ameliorate trade relations with neighboring Central Asian countries (Pannell and Ma 1997; Yessengaliyeva and Kozhirova 2016). The initiative introduced by the Chinese government in 1986 to settle nomadic pastoralists and introduce them to agro-pastoralism (Congress 2002) aims to counteract overgrazing and grassland degradation (Sayilan 2011) caused by the disproportionate increase in pastoral populations to livestock output, but the socioeconomic benefits are so far not pronounced.

Case studies in Western China have consistently shown that reducing herding range is ineffective for increasing forage availability (Liao et al. 2014) and for combating the effects of overgrazing and climate change (Dong et al. 2011; Shinjilt 2010; Yeh 2009). Such practices contravene TEK (traditional ecological knowledge), an invaluable reference for devising sustainable measures (e.g., Humphrey and Sneath 1996; Wolverton et al. 2016). In Xinjiang Uyghur

${ }^{1}$ University of Pennsylvania, Department of East Asian Languages and Civilizations, 255 S. $36^{\text {th }}$ St., Philadelphia, USA (annic@sas.upenn.edu) 
Autonomous Region, where traditional herding practices are forced to yield to state goals to simultaneously stimulate pasture productivity and the market economy (Liao et al. 2015; Shinjilt 2010; Xun and Bao 2008; Yeh 2009:886), skills of traditional production that were once central to sustainable pastoral livelihood, such as the making of milk products (Lu 2010:33) and felt (Feng and Aimaiti 2008:115), are rapidly losing their economic and social currency.

Artisanal crafts are broadly synonymous with artifact, heritage, ethnic art, and tourist attraction, with little bearing on pertinent social policies that aim to better the livelihood of resettled pastoralists. As a result, such crafts are often conveniently assigned to the patronage of the administration of "intangible cultural heritage," whose categories are manifold (Shepherd and Yu 2013; State Administration of Cultural Heritage 2008). So-called green products, in the case of dairy, are hyped for their ecological authenticity and purity (Tracy 2013; Xun and Bao 2008), yet TEK in general is dispensed with (Liao et al. 2014).

To illustrate the perpetuation of the making of milk products and felt in domestic livelihoods, I present two field observations of pastoral production in Bortala Mongol Autonomous Prefecture and discuss these results with reference to existing ethnographic literature. The discussion excludes the economy of wool and milk acquisition, which falls under a different legislative purview. I argue that these pastoral crafts, once fundamental to a sustainable mode of pastoralism, are becoming what current productivity and developmental targets consider "extraneous," even though they carry valuable TEK that could help promote cultural heritage and bolster local economies.

\section{Background: The Effects of Current Reforms on Pastoral Life}

The province-wide transition from year-round herding to sedentarization and agro-pastoralism in Xinjiang is heralded as a guaranteed path to elevating pastoral productivity and the standard of living (Feng and Aimaiti 2008:116). Lei's (2011) field study in Bortala details changes the ethnic minority groups experience after their resettlement. Moving from yurts into new urban housing (Pannell and Ma 1997:220; Sayilan 2011:71) renders the convenience of using electrical appliances and better sanitary conditions. These groups receive allowances and are allocated vegetable patches and animal pens. Funding for machinery and programs that educate the youth on crop planting techniques and agricultural technologies are offered (Feng and Aimaiti 2008:115). Public infrastructure and cooperatives are set up to provide employment and support increasingly industrialized scales of production in conurbations of rural municipalities (Pannell and Ma 1997:219; cf. Xun and Bao 2008).

But policies promulgated to assimilate pastoralists into urban living and a sedentary subsistence have seen limited progress. Government subsidies are of limited assistance to those who begin crop cultivation and small businesses (Liao et al. 2015). Income disparities and social gaps continue to widen (Shinjilt 2010). Competition from military farms instituted by the Xinjiang Production and Construction Corps in support of large-scale Han Chinese in-migrations since the 
1950s poses further obstacles to making a good profit from selling agricultural produce. With the rising cost of fodder, new farmers are struggling to attain a profitable level of agricultural output, thus, many still subsist primarily on mobile husbandry (Lei 2011). Notwithstanding shortcomings of the resettlement campaign, Chinese scholarly literature has consistently championed the economic benefits of sedentarization (e.g., Feng and Aimaiti 2008; Lei 2011; Ma 2008; Sayilan 2011).

The campaign's struggle to attract sedentarization is not solely financial, however. Pastoralists that Cerny $(2008: 214 ; 219-220)$ interviewed in his field of study were anxious about affording urban living and adapting to a different habitat. While the campaign paints a glamorized prospect of sedentarized pastoralists living as shrewd consumers and businessmen and as citizens who embrace modern living (Feng and Aimaiti 2008), the pastoralists remain ambivalent about relocating (Cerny 2008; Lei 2011; Sayilan 2011). At the same time, housing supply fails to meet settlement targets (Ma 2008:1198) and building quality is often substandard.

The campaign's goal of full sedentarization by 2015 (Lei 2011:1) is still far from reach. In the preceding decade, the percentage of pastoralists that meet government standards of sedentarization hovered below 40\% (Feng and Chu 2010; Ma 2008; Sayilan 2011); the majority maintained the practice of year-round herding. The new target is to sedentarize 169,000 households, i.e., about $50 \%$, by 2020 (Sayilan 2011), a challenging prospect given the average percentage increase between 1996 and 2006 (Feng and Chu 2010). Proponents, however, believe that resistance to settlement can be alleviated by implementing better infrastructural support and educational programs.

The setback is, however, likely attributed to the misalignment of economic, social, and ecological goals at the outset (Cerny 2008:210). The idea to sedentarize nomads in the name of tuimu huancao (retire livestock, restore grassland) (Shinjilt 2010; Yeh 2009) has proven to be neither ecologically sound nor socially beneficial (Cerny 2008). Research in Xinjiang (Liao et al. 2014; Liao et al. 2015), the QinghaiTibetan Plateau (Dong et al. 2011; Yeh 2009), Inner Mongolia (Shinjilt 2010; Xun and Bao 2008), and Mongolia (Humphrey and Sneath 1996:18) has consistently showed that pasture fencing, land division, and grazing bans rehabilitated neither the pasture nor the people, but have instead increased the "vulnerability" i.e. "passim": (Dong et al. 2011) of pastoral livelihood. Promoting sedentary husbandry has not helped boost pastoral production either (Dong et al. 2011; Xun and Bao 2008). Herders note the dilemma between the need to raise more livestock to boost income and the availability of good quality pastures (Cerny 2008:213), a question of sustainability the campaign has yet to address.

The collective implementation of TEK and herding norms (FernandezGimenez 2000:1318; Wolverton et al. 2016), based on a heuristic approach to synchronize migration patterns with vegetation dynamics (Liao et al. 2014), may be the key to sustainable resource management. However, this has proven challenging in China where ecological interests are heeded in policy and publicity but hardly in practice (cf. Shinjilt 2010; Yeh 2009). The campaigns for new economic and social policies are quick to proclaim new paths to productivity and modernization, but remain generally unconcerned with the contingencies of TEK loss, as well as the urgency of formulating sustainable alternatives to what were vital means and methods of pastoral subsistence. 


\section{Methods}

\section{Study Region}

Representing one-fifth of China's natural pasturage (Zheng and Chen 2005:436), Xinjiang's grassland occupies a third of its administrative area (Lu 2010:33). Bortala Prefecture is located in the northwestern-most part of the province and shares an international border with Kazakhstan (Figure 1b). It comprises two counties, Wenquan and Jinghe, and has two county-level cities, Bole and Alashankou (Atwood 2004:46). Pastoralism is the second largest sector of the local economy, after agriculture. Sheep (Ovis aries), goats (Capra aegagrus hircus), cattle (Bos taurus), horses (Equus ferus caballus), and Bactrian camels (Camelus bactrianus) are herded. Wheat (Triticum spp.), sunflower (Helianthus annuus), corn (Zea mays), potato (Solanum tuberosum), and beetroot (Beta vulgaris) are the most common crops cultivated in Wenquan, where aquaculture of cold water fish is also practiced.

The main herding areas are located on the montane grasslands on either side of the Bortala River (Figure 1a), the main watercourse that fans out from a mountain pass coterminous with the China-Kazakhstan border at the intersection of Tian Shan and the Dzungarian Alatau. The river travels east-west and drains into Lake Ebi, an endorheic salt lake in the Dzungarian Basin. Extensive pasturelands are also found on the banks of Lake Sayram, the other lake in the prefecture at the foothills of Tian Shan.

Besides having the most cattle per capita, Xinjiang also has the largest number of horses, donkeys (Equus africanus asinus), and camels in the country (Lu 2010:31-32). Products made from milk of animals, including horse, camel, sheep, goat, and cattle, are pastoralists' staple foods. The output of milk products in 2007 is estimated at 203,600 tons ( $\mathrm{Lu}$ 2010:31). Milk distribution and consumption, however, remain domestic and localized. Only $20-30 \%$ of its milk products are made for commercial sale (Lu 2010:33).

With over 12 million sheep and an output of fine sheep wool at 28,700 tonnes (2003 figures), Xinjiang has supplied between $10 \%$ and $15 \%$ of the market share of fine wool in the last decade, second nationally (Zheng and Chen 2005:434). Demand for Xinjiang wool exceeds that for its wool products. The price index shows that, despite its uneven quality, wool from Xinjiang is only of lesser value than from Inner Mongolia but remains competitive against exports from the provinces of Gansu and Qinghai (Zheng and Chen 2005:436).

\section{Demography}

This study is focused on two ethnic groups, Mongols and Kazakhs, who respectively represent nearly $10 \%$ and approximately $80 \%$ of nomadic pastoralists in Xinjiang (Sayilan 2011:71). Non-Han ethnic groups, of which Uyghur (13.32\%), Kazakh (10.01\%), Mongol (5.66\%), and Hui (5.22\%) constitute the majority, represent one-third of Bortala's population of nearly 450,000 (Population Census Office et al. 2012). Established as a Mongol Autonomous Prefecture in 1955, Bortala's political status is attributed to its history as a resettlement area for the Chahar Mongols who migrated from Inner Mongolia and central China by order of 


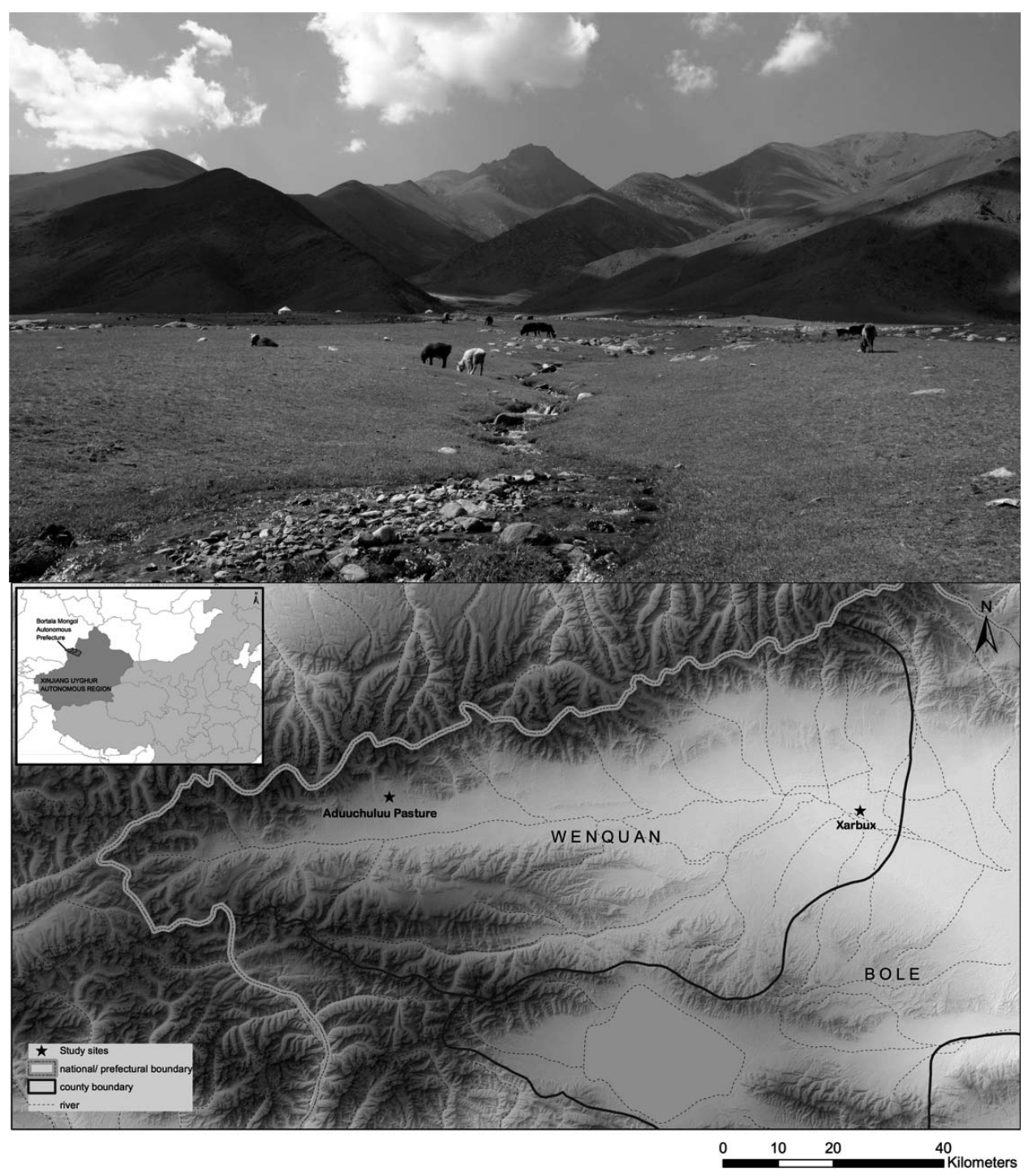

Figure 1. a) the grassland of Bortala River Valley (top); 1b) map of study region and sites (bottom).

the Manchus of Qing China in the 1750s (Atwood 2004:46, 89; Di Cosmo 1998:298). This was also when the Torgut tribe of the Oirat Mongols, who fled Dzungaria in the seventeenth century, returned from the Volga River region and resettled in today's Xinjiang, primarily in Jinghe, Bayingolin, and Bortala (Soni 2010).

The Kazakhs share a similar history of relocation. A great number moved to Dzungaria, on account of the Manchu resettlement scheme, but the continual influx stems from the Kazakh diaspora from Kazakhstan fleeing Soviet oppression at the beginning of the twentieth century (Benson and Svanberg 1998). The majority of the Kazakh population in Xinjiang is presently found in Ili, Altai, and Tacheng. 


\section{Study Sites and Participants}

The field observations took place at two sites in Wenquan County: a winter pasture in the upper river valley and an agricultural town on the alluvial plain. Word of mouth was the best way to locate practitioners because the making of milk products and felt-making are carried out domestically. Felt-making is especially rare and privy to family members. The practitioners were introduced informally through the author's fieldwork connections. Verbal permission was obtained from the practitioners prior to data collection.

\section{Data Collection}

The field observations took place over four non-consecutive days. The search for willing practitioners occurred intermittently during a three-month-long archaeology field season in the Bortala Valley. Data were collected in the form of videos and stills. The interviews were intermediated by local bilingual interpreters and the questions concern mostly the techniques of production and associated customs. Owing to access restrictions in the border regions of China, only two case studies were conducted. Despite the small sample, the data presented here offer a unique insight into how pastoral crafts are practiced in Bortala today and the associated socio-economic changes. The limited scope of this research nonetheless points to a need for a more extensive study, provided that access to further data is possible in the future.

\section{Case Study I: Making Mongol Milk Products}

The study took place on July 22, August 2, and August 3 of 2014 in a Mongolian household of three (father, mother, and son) at Aduuchuluu (Adunqiaolu 阿敦喬魯) Pasture north of the Bortala River at ca. 2000 masl. The family is commissioned by the government to station at Aduuchuluu year-round to oversee pasture use. They have their own herds but they are also contracted to tend to other families' livestock (cf. Liao et al. 2015:1313). Their residence comprises three structures: a green army tent, a traditional Mongol yurt with a composite fabric covering reserved for receptions, and a single-story cement and stone building that houses the living quarters. The building adjoins a cooking area enclosed on two sides by wooden planks and covered by a canvas shade on the third. The milk products were made on site with homegrown cow's milk. The mother assumes the responsibility of making these milk products; she is assisted by members of her household and extended family. The author's Mongol coworker, who was the interpreter, arranged for the observation.

Cows are the primary producers of milk in Bortala; goat's milk and kumys (fermented mare's milk) are also habitually consumed. Camel's and sheep's milk are less common. Black tea brewed with milk is drunk daily and served as a welcome drink. Fermented sheep milk and goat milk are not commonly produced because yields are not sufficient for mass consumption. Camel's milk and kumys are offered as delicacies to important guests. 
The principal methods of milk processing include boiling, churning, fermenting, distilling, and drying, by which fresh milk is transformed into different milk products, many of which can be kept in long-term storage and consumed throughout the year. The processing techniques Mongols and the Kazakhs employ belong to the same geo-cultural scheme according to Hirata's (2003) dualistic classification of milk cultures, but because different additives and apparatuses are used, their milk products have different tastes and textures. The following describes milk products that Mongols in Xinjiang make regularly, how they are made, and the chemistry of each stage of processing. Colloquial names are used; the Mongol and local Chinese terms are provided in parentheses.

\section{Boiling and Churning}

To make white butter (öröm, suyou 酥油), fresh milk is heated and left to cool inside the yurt. A solidified cream layer, which is the milk skin (naipizi 奶皮子), forms on the surface. This cream is collected into a pot and churned by hand until it coagulates into a paste, which is white butter (Figure 2c). Butter is served as a flavoring for tea and a spread for naan, which is usually torn into pieces to accompany a meat dish (Zhou 1994:44).

In a separate interview with a Kazakh family, it was explained that fat extraction makes for more acidic kefir and less buttery cheese, which is better for storage.

\section{Churning and Fermenting}

After the cream layer is scraped off, the milk is poured into a churn and a starter is added to make kefir (islegen tarag, suannai 酸奶) (Figure 2b). The starter introduces microbacteria to the milk to induce fermentation. Instead of a cloth churn, mare's milk is fermented in a leather churn (Degen 2007:10; Zhou 1994:40). The bacteria digest the lactose in the milk, encourage curdling and the coagulation of protein molecules, and reduce the $\mathrm{pH}$ level, which gives kefir its acidic taste. The churn used here is a waxed cloth sack of roughly a meter high. It hangs upright inside a small lightproof army tent where the absence of light promotes bacterial activity (Figure 2a). The milk is churned regularly with a long wooden stick in a piston-like motion (Degen 2007:10), adding oxygen to the working of the starter culture.

\section{Drying}

Dried milk curds (aaruul, naigeda 奶疙㾂), whose Chinese term literally means "milk lumps," are air-dried cheese made from curdled kefir. After the kefir is prepared in the churn, it is placed in a separate container to curdle. This process takes a few days depending on temperature and humidity. The curdled kefir has a blobby texture composed of caseins (the solids) and whey (the liquid) that contains water-soluble proteins (Figure $2 b$ ). The kefir is hung in a cloth sack to drain off the liquid, which takes a day or two. What is left is a white soft dough with the texture of commercial goat cheese, which is then molded into flat half palm-sized pieces and dried on a bamboo mat outdoors. The cheese is ready in a few days when it dries, hardens, and turns yellow (Figure 3c). Milk curds can be preserved for years when stored correctly. Because they quench thirst and are 


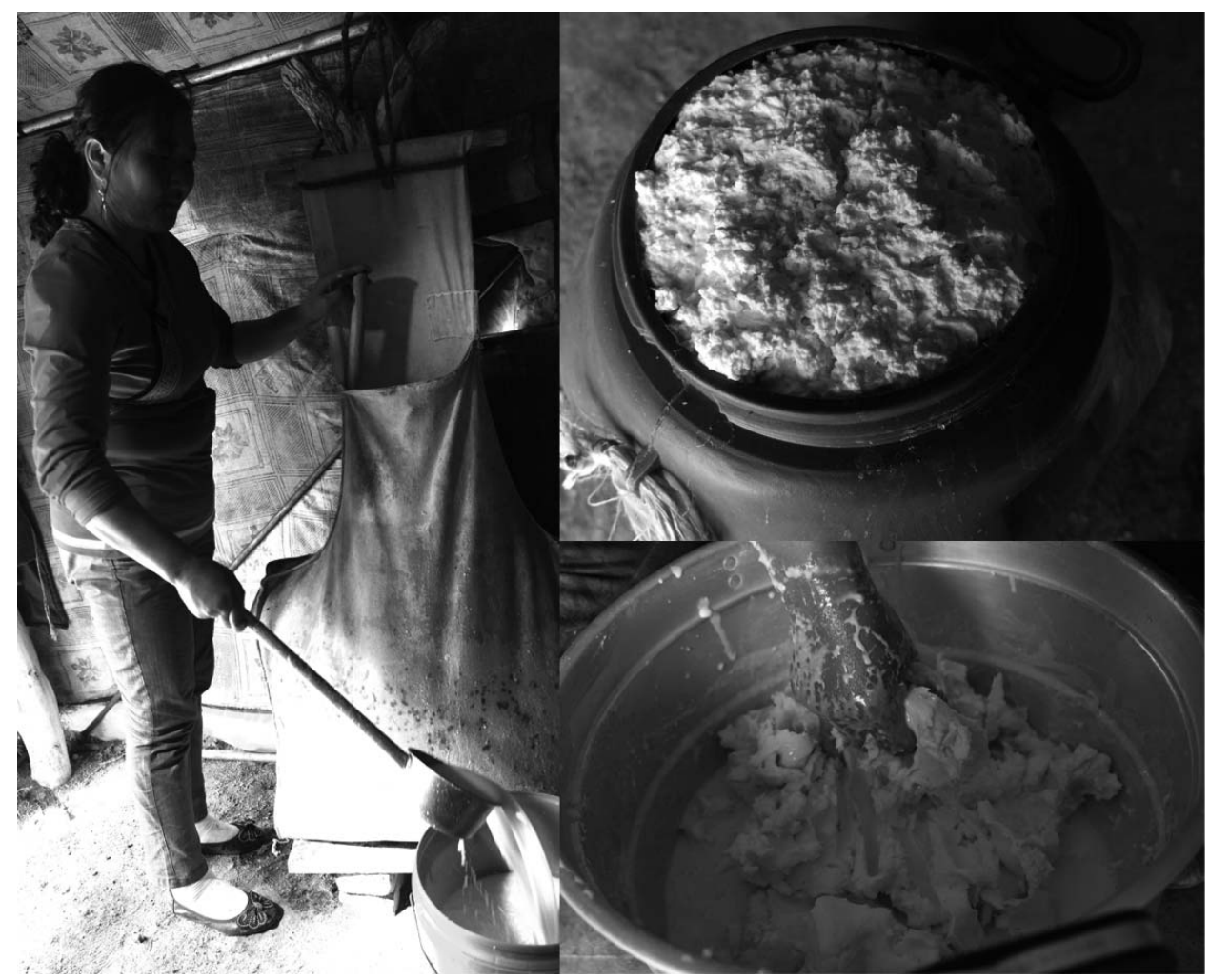

Figure 2. (Clockwise from left) a) Retrieving prepared kefir from cloth churn; b) curdled kefir for cheese-making, also used as starter culture; c) churning cream to make butter. (Source: author's photos).

nutritious, they are a popular snack for long distance travels. The Kazakh milk curds are shaped as small round cakes; they have a distinctly more acidic taste than the Mongol curds.

\section{Distilling}

Milk liquor (arkhi, naijiu 奶酒) is an alcoholic beverage that is distilled from kefir, though, in Inner Mongolia, it is also made from kumys and camel's milk or a mixture of various kinds of milk (Montell 1937:325, 331). It is a Mongolian specialty beverage. Prized for its subdued aroma and high nutritional value, milk liquor is a welcome and celebratory drink. The liquid is clear and is usually drunk hot. Butter can be added to enhance the flavor. When distilled several times, the liquid becomes stronger (Montell 1937:325). Though widely consumed among the Mongols, it is rarely available commercially, likely because the process is complex and involves the use of a traditional still (Luo 2012).

The kefir is poured into a wok that sits on top of an adobe stove with two chimneys. A top-and-bottomless wooden barrel is placed upright in the wok (Figure 3a). Inside the barrel, a wooden bucket to collect the distilled liquid is suspended by ropes attached to the barrel exterior (Figure 3b). Another wok, which 


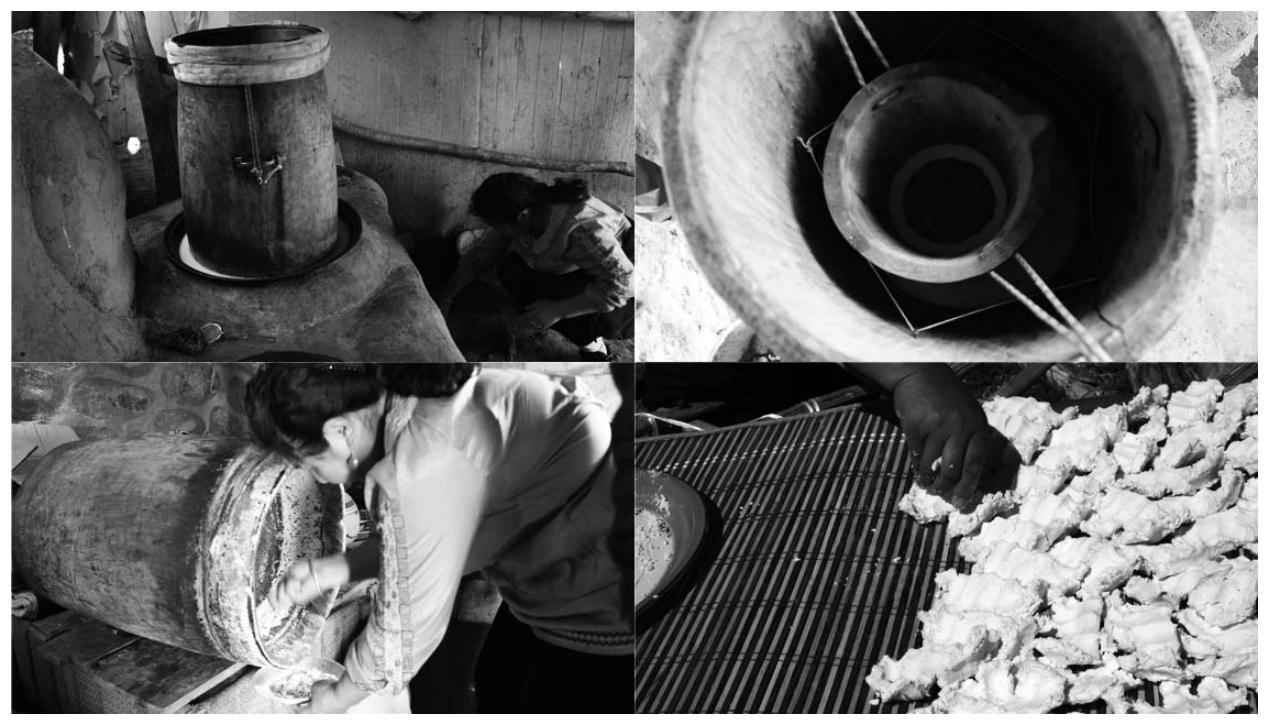

Figure 3. (Clockwise from top left) a) setup of milk distillation apparatus; b) a wooden bucket is suspended inside the barrel to collect the distilled liquid; c) soft cheese pressed into flat, crinkled shapes is air dried into hard curds; d) the residue from the barrel interior after distillation is cottage cheese. (Source: author's photos).

serves as the condenser (Luo 2012:504), sits on top of the barrel. It is refilled with cold water periodically during distillation, which takes roughly an hour. A strip of fabric is wrapped tightly around the mouth of the barrel to keep it airtight.

When the setup is complete, firewood is added to the stove. The liquid collected in the wooden bucket from condensation is milk liquor. It has an alcohol content of about $10 \%$ and is usually drunk hot. The soft cheese curds clumped on the inside of the barrel can be consumed as cottage cheese or used to make dried milk curds, the flavor and nutritional value of which are, however, inferior to those made from freshly curdled kefir (Figure 3d).

\section{Case Study II: Kazakh Felt-making}

The process of felt-making was observed in the town of Xarbux (Haribuhu 哈日布呼). As displayed on the finished felt rug, the date was August 12, 2014. It is common to find the production date and the name of the practitioner embroidered on Kazakh felt rugs.

The author was introduced to one of the practitioners through a Kazakh coworker; the other two are related to her as sister-in-law and aunt-in-law. The feltmaking took place in the courtyard of the aunt-in-law's residence that includes a brick and cement building. The interior is furnished in traditional Kazakh style, mimicking arrangements inside a yurt. The raised platform and the walls are covered with either machine-made or handmade rugs and fabric coverings. In the corner of an anteroom is a pile of felt rugs stacked under pillows and bedding. 


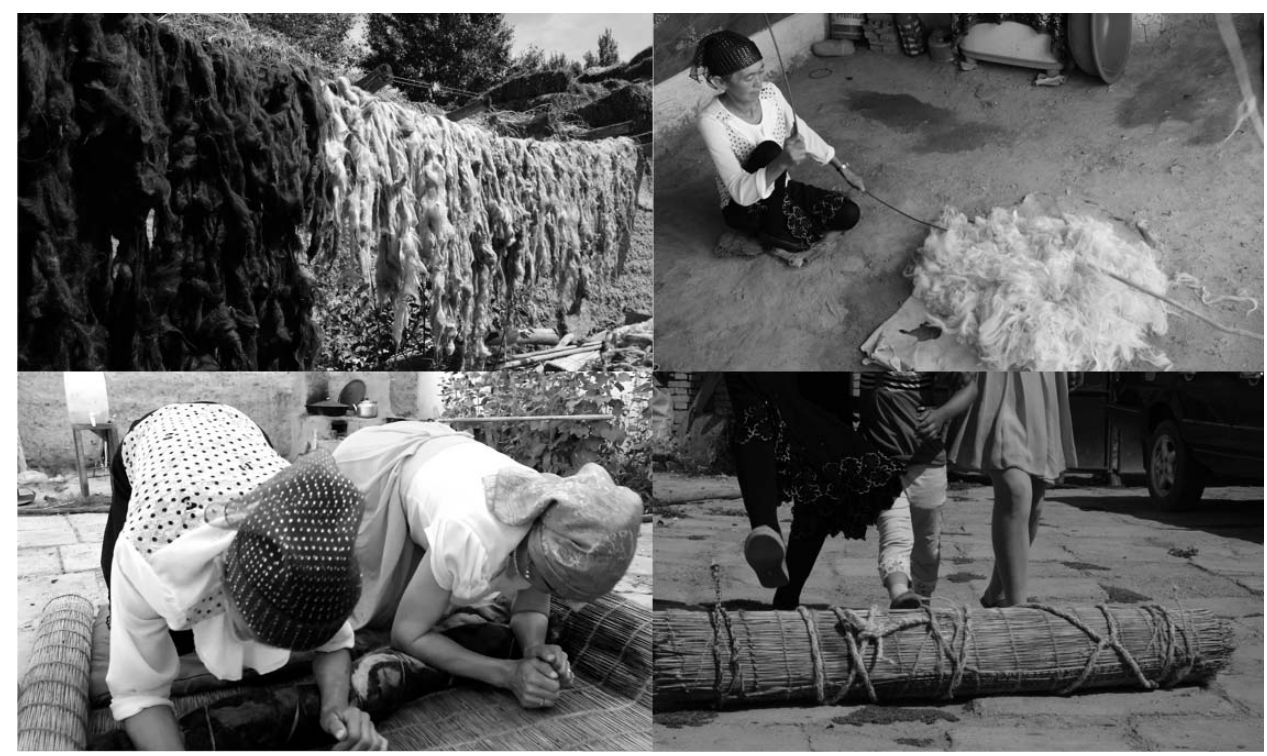

Figure 4. (clockwise from top left) a) washed wool hung to air dry; b) beating wool; c) kicking the roll to work the fleece inside into a compressed mass; d) rolling and pressing the felt roll. (Source: author's photos).

In Bortala today, the practice of felt-making remains domestic, but is becoming increasingly uncommon following the large-scale settlement of pastoralists into urban areas where felt-making outdoors becomes improbable. Making felt rugs and coverings is less essential, as pastoralists move out of their traditional yurts. Those who moved into new housing estates in Wenquan County have started using synthetic rugs for easier upkeep and a lower risk of moth infestation (Zhou 2006:88).

I will not reiterate information on techniques of felt-making and felt designs that has been copiously documented in ethnographic literature and textile studies (e.g., Bunn 2010; Burkett 1977; Eiland 2007; Laufer 1930; Mullins 2009). I describe below how the chemical effects relate to the physical properties of wool at each stage of felt-making.

\section{Washing}

Lamb fleece that has been washed with soap and hung to air dry (Figure 4a) is strewn in heaps against a wall in the courtyard. Washing detaches any fecal and vegetable matter from the fleece. Sheep's wool is most commonly used because of how well it felts. The scales on its fiber react to heat and moisture during felting; the finer the fiber and the more crimp (waviness) it has, the better it felts (Mullins 2009). Where available, lamb's wool is used because it is finer and makes for softer and more pliable felts (Mullins 2009:8).

\section{Beating}

The fleece is formed into a small pile on the ground and thrashed repeatedly with two thin metal or wooden sticks in a two-beat rhythm in alternation 

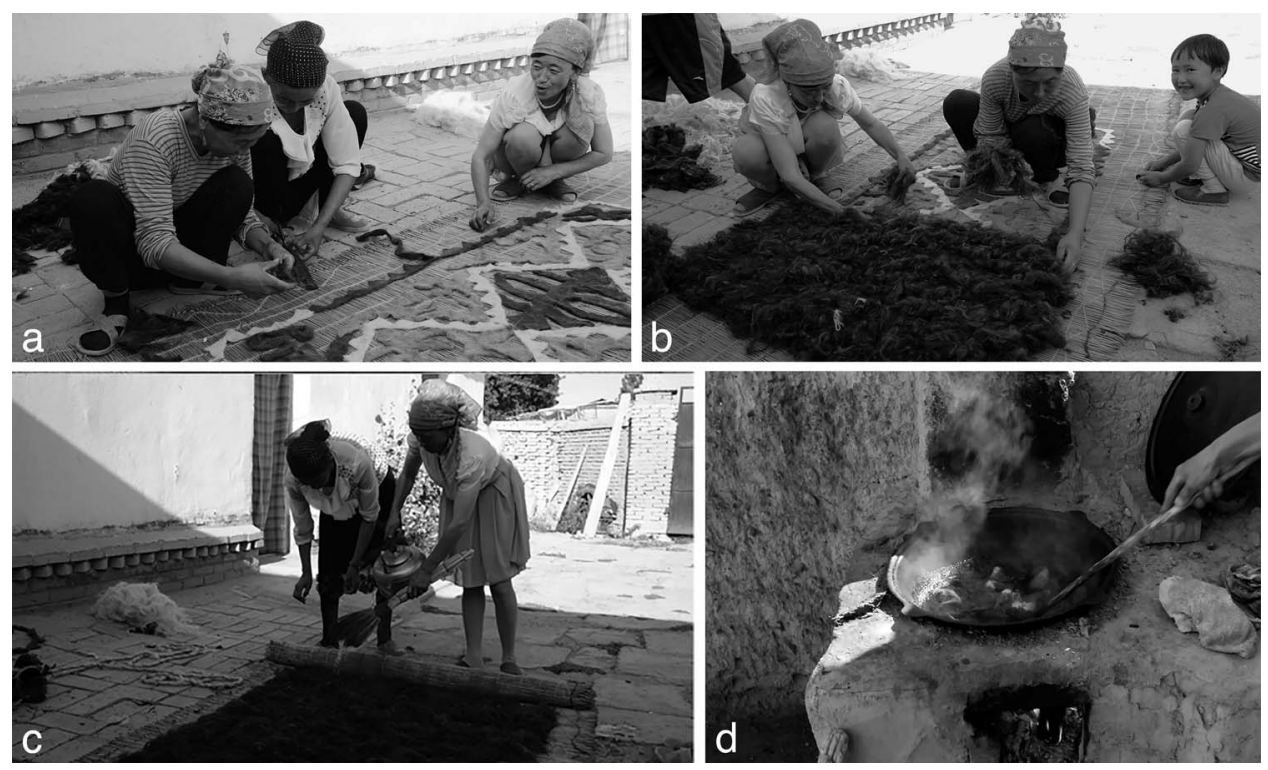

Figure 5. (clockwise from top left) a) arranging the colored patterns; b) overlaying with brown fleece as the base layer; c) sprinkling the wool with hot water; d) dyeing felt in boiling water. (Source: author's photos).

between two practitioners (Figure 4b). This loosens the fibers from the staples, sheds trapped dirt particles, and filters out the matted wool, leaving the finer and longer fibers for felting (Laufer 1930:13). After 20 to 30 minutes of beating, the fleece is laid in thin overlapping patches on a handmade reed mat (Figure 5b).

\section{Adding Hot Water}

Next, hot water is sprinkled on the fleece until damp (Figure 5c). Chemical experiments show that the hydrophobic nature of the fiber surface promotes the flocculation of wool fibers (Stigter 1971). In the absence of aqueous media, the directional frictional properties of wool diminish significantly, whereas swelling wool fiber enhances felt-ability (Bogaty et al. 1951:823; Bohm 1945). Hot water helps dissolve the waterproofing lanolin to open up the scales on the fiber to allow it to absorb moisture (Batchuluun 2003:66). Wetting the wool with hot water is widely documented in pastoral felt-making traditions (Eiland 2007:275, 277; Laufer 1930:13).

\section{Rolling}

After the fleece is dampened, the reed mat is rolled up with the fleece coiled inside. It is secured by fastening cords on both ends that are tightened throughout the process. It is then rolled on the ground by repeated stomping and kicking by more than one person (Figure 4c); children are usually eager to join in (Laufer 1930:13). The application of friction and pressure induces a mechanism known as "creep" (Burkett 1977; Mullins 2009), whereby the tips of the fibers travel to their root ends, causing them to entangle (Eiland 2007:275, 277; Menkart and Speakman 1947). The rolling and kicking takes at least 30 minutes. 
When felting is carried out on grasslands, the roll may be dragged around by horses for a decent distance (Laufer 1930:13; Raina 1993:83).

Some ethnographic accounts refer to the process described hitherto as prefelting, the first stage of felting that they distinguish from the second stage called fulling. Pre-felting involves tangling the fibers to form a "semi-structured mass" (Bunn 2010:33). In Turkish felting, this stage involves adding tepid water, pressing, and rolling. Fulling refers to the further shrinking, linking, and matting of the wool to achieve the effect of felting, although this term is more often used to describe the felting of woven or knitted fibers.

\section{Dyeing and Laying Out Patterns of Design}

After the first rolling, the design of the rug is laid out. Here, a natural brown wool backing is overlaid with color curvilinear patterns, which is a popular Kazakh style (Figure 5a). To make the colored patterns, first, a piece of damp white felt is placed in boiling water with a chemical dye and a small handful of salt (Figure 5d). After the desired amount of color saturation is achieved, the felt is hung to drain off excess water. The process is repeated to obtain pieces of different colors. When the felt is slightly damp to the touch, the patterns are stenciled with charcoal and the design is cut out. They are then arranged in the mirror image of the design and brown fleece is overlaid to serve as the base (Figure 5b).

This process described henceforth is roughly equivalent to what is described in the literature as "fulling." The process of adding hot water (Figure 5c) and rolling and kicking (Figure 4c) is repeated to fuse the cut patterns to the base. The felt is then extracted from the reed mat and rolled. Two practitioners simultaneously roll and press the roll in a forward motion with their forearms for 20 minutes (Figure $4 \mathrm{~d}$ ). The felt is then unrolled and air dried for a few days.

\section{Discussion}

In the long history of pastoralism, the exploitation of animal secondary products is a critical strategy of resource use. Chief among these products are milk and wool, which are ready and renewable sources of material for maintaining a pastoral livelihood. With reference to the two case studies, I contend below that the history and socioeconomic value of these practices are important factors to consider in state reforms of pastoral practices. I discuss this in three regards, namely, lineage, prevalence, and practice.

\section{Milk Products}

Discoveries of the earliest lipid residue from pottery sherds from sites across southeastern Europe, Anatolia, and the Levant (Evershed et al. 2008) suggest that milk processing was widely practiced in West Asia after the seventh millennium BC and probably originated there (Hirata 2003). As peptide signals extracted from masses of cheese at Xiaohe Cemetery in the Tarim Basin suggest, milk fermentation by microorganisms was practiced in Inner Asia as early as the second millennium BC (Yang et al. 2014:185). Chemical analysis of fermented 
milk products (Uchida et al. 2007; Xu et al. 2014) corroborates ethnographic observations of the use of domestic starters from old fermented milk and inherited recipes for making fermented products (Montell 1937:327). The starters are distinctive of the microbiota of the environment in which they develop and show that fermented milk products, though ubiquitous in pastoral communities, are a localized food heritage.

Distilling liquor from milk appears to be a later invention, as the earliest references in historical texts appear no earlier than the Yuan Dynasty (thirteenth century AD) (Luo 2012:passim). There are speculations that a type of Chinese still, of which the earliest archaeological examples dated roughly to the Yuan Dynasty, were discovered in Inner Mongolia and Hebei and could have been used to distill kumys. These claims, however, remain unsubstantiated (Luo 2012:489-498). The methods of production in the case study largely conform to what has been documented in scientific studies and ethnographic accounts, suggesting that there is a strong continuity of production tradition in the making of milk products. But how this TEK can be effectively channeled into devising economically and socially sustainable reforms is inadequately researched.

In Bortala, the common milk products the Mongols and the Kazakhs produced domestically can be divided into a few broad categories: in liquid form as milk, fermented milk, buttermilk, and kefir; in semi-solid form as butter and yoghurt; and in solid form as soft and hard cheeses. They are consumed as beverages, snacks, a meal, or used as seasoning and a condiment. Foods produced artisanally embody a domestic affinity with their traditional sustenance; they also carry important social and ritual values. Starters used in domestic production of milk are recycled from old kefir and circulated among one's kin. For both the Mongols and the Kazakhs, milk is the color of the sacred, the auspicious. It is a symbol of rich harvest and good will (Zhou 1994:41-42), thus, widely employed as a gesture of hospitality. Accounts in Mongol history attest to the extensive application of kumys in ceremonies of worship and celebration as tokens of tribute and veneration (Serruys 1974). Kumys is also prized for its benefits to digestive and reproductive health (Atwood 2004:322; Zhou 1994:41). Assorted taboos related to the use of milk and milk products are still observed today, some of which are narrated in folklores and folk songs (Zhou 1994:42). For instance, a traveler should not carry butter so as not to bring bad fortune to the household; pregnant women should not drink camel milk (Zhou 1994:43-44).

In Xinjiang and Inner Mongolia today, a weak market potential and inadequate quality control have hampered the push to industrialize the manufacture of traditional milk products. Local demand for commercial milk products is limited since the pastoral populations prefer to source their milk and milk products through their kin when they do not produce their own. Decentralized husbandry and feeding, hand milking, and poor sanitary

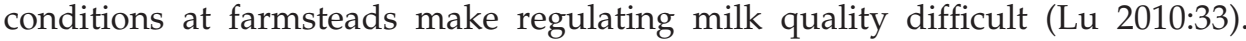
With competition from high quality imports, especially from Inner Mongolia, Australia, and New Zealand, Xinjiang exports have struggled to gain traction in domestic and international markets (Lu 2010:33). Small-holders scarcely stay afloat facing state-supported monopolization by corporations like the Mengniu 
Group, whose industrial-scale productions exacerbated the undesirable effects of controlled herding and ecological relocation instituted in the name of ecology and productivity (Xun and Bao 2008).

Meanwhile, there is ongoing research on cultures and anti-bacterial treatments to improve the quality of commercial kefir, yoghurt, and camel milk products (Lu 2010:32). Tracy's (2013) ethnographic research in Inner Mongolia reveals, however, that the deployment of dairy technoscience remains illconceived and falls short of aspirations of terroir that appear to be sustained so far by ostentatious advertisements of unspoiled grasslands and the promotion of products under the banner of "Green Food."

The traditions of making milk products prescribe culinary methods and schedules of production specific to different regions and types of milk. The case study indicates that Bortala shares similar practices of making milk products with pastoral groups in Mongolia and Inner Mongolia. Considerable differences in terms of additives and processing techniques can be found when compared to traditions further to the west, such as in Turan, Iran, where products are made mostly from goat's milk and supplemented by cow's and sheep's milk. Rennet is used instead of a starter culture to make cheese and a large part of the milk processing involves heating (Martin 1980, cf. Farahani et al. 2014).

As staple foods in pastoral households, milk products are assigned different schedules of production to accommodate daily consumption and ensure excess for seasons of low yield (Degen 2007:10). The product's culinary uses and physical properties also determine how it is processed and stored. For the benefit of taste and texture, fat is usually extracted from cow's milk prior to further processing, but not for mare's milk and camel's milk. Cheese made from whole camel's milk has higher protein, fat, and sodium, a more brittle texture, and a stronger taste (Ishii and Samejima 2006). Dried milk curds, generally made from cow's milk, can be stored without refrigeration for long periods of time so it is produced in bulk when milk yields are high. Kumys is not suitable for long-term storage (Zhou 1994:40); it can, however, be made into milk liquor to prolong its preservation. Milk products, including butter, yoghurt, and cheese, can be stored in casings made from cleaned sheep's or cow's stomach (Zhou 1994:40), goat and horse intestines, and leather sacks (Minzhigdorj and Erdenebaatar 1993:49), but these vessels are rarely used today, since plastic, ceramic, metal, and fabric containers are widely available.

The labor-intensive multi-stage process of making milk liquor shows that a strong custom of domestic and collective food production is the basis for the transference of culinary knowledge through generations. The type of still observed in this case study has also been documented in Gansu Province (Luo 2012:504). Montell (1937:28, Figure 4) described a still of an alternative design in Inner Mongolia - a large cauldron with a vaulted lid tightened with clay. Milk is poured in through a hole in the lid and the steam exits from another into an iron pot. The dominance of milk products in pastoral diet and customs, and the distinctiveness of the production methods, make for a long-standing tradition that merits attention in present reforms. 


\section{Felt}

The centers of felt-making traditions are distributed along a latitudinal axis through Eurasia from China to Turkey, congruent with where pastoral nomadism developed. Likely representations of felt works on wall paintings discovered at Çatal Hüyük suggest that felt may have been in use as early as the seventh millennium BC (Bunn 2010; Burkett 1977:112-113), which is not unlikely since sheep and goat were domesticated as early as 10,000 BP in the Near East (Laufer 1930:1; Zeder and Hesse 2000). The earliest remains of felt were dated to the second millennium BC and discovered in Eastern Eurasia in remarkable condition. Felt-lined boots, felt socks, and conical felt hats are typical of funerary attire discovered in the Tarim Basin (Abuduresule et al. 2004). Ornate patterns and fine embroidery of carpets and wall hangings at Pazyryk and Noin Ula (Trever 1932) closely resemble designs of contemporary felts from Mongolia (Bunn 2010:20), illustrating the antiquity of felt-making as a craft that was, by the end of the first millennium BC, prevalent and very advanced.

For its light, pliable, water-resistant, and insulating qualities, felt was a ubiquitous material in nomadic pastoral societies. Traditional yurts covered by felt are an unmistakable symbol of nomadic architectural culture and extensively documented in medieval travelers' accounts and Chinese historiographies (Gervers and Schelpp 1997). Felt was also widely used in transportation as saddles (Gervers and Schlepp 1997:97-98), covers for personal belongings during transit (Laufer 1930:6), and to make pouches and quivers. The use of white felt rugs as blessed articles in ceremonies among the Turks and Mongols is extensively documented in early modern historical literature (Laufer 1930:12).

Nowadays, felt has practically been replaced by machine-made fabrics more compatible with urban living. Instead of a felt covering, yurts used in Bortala are now composed of a cotton-synthetic composite cover over a metal frame. Felt rugs of fine craftsmanship are still valued for interior decor, even in modern apartments, but they are mostly esteemed family heirlooms or works of art. Handmade felt articles, like rugs, are rarely sold commercially; they are distributed through familial or social connections, like among Turkish peoples and in Mongolia (Raina 1993:84). At the same time, there is limited commercial interest in artisanal felts that are now considered symbolic more than functional and rely on a labor-intensive and time-consuming process; machine-made rugs are preferred for their relative affordability and availability. In Bortala, the younger generation generally considers felt-making practice antiquated, but tapping their interest could be a means to develop a profitable market for these endangered ancient skill sets (Zhou 2006:88-89).

What is disconcerting, however, is that practical measures to explore the exclusive economic value of pastoral crafts currently take a backseat to promoting their heritage currency in ways that do not necessarily bring direct financial benefits to their practitioners. Artisanal skills, such as felt-making, are turned into fetishized objects of cultural tourism and default ethnological exhibits, thrown in with ambiguous connotations of "heritage" (Shepherd and Yu 2013:2) to accommodate the rhetoric of reviving the national narrative and constructing the postmodern Chinese aesthetic of re-assimilating the traditional and the historic into the contemporary. 
In Bortala, felt-making is occasionally held as a communal ritual at Lake Sayram. This is also the case in Mongolia. The process is sanctified with words of blessing to bestow "auspicious qualities to the felt" and "bring good fortune to the feltmakers" (Batchuluun 2003:63, 67). Milk is sprinkled on finished felt as an act of blessing and to enhance its water resistance (Batchuluun 2003:63; Laufer 1930:6; Raina 1993:83; Serruys 1974:1). Although ritual aspects of felt-making were not noted in this study, the collective appreciation of workmanship and communal labor was evident. There was a strict fidelity to the process of production and the felt designs represent the execution of cultural aesthetics cleaved to age-old customs of distinct pastoral ethnicities. How best to harness the qualities of wool is also anchored to inherited techniques of animal husbandry (Fernandez-Gimenez 2000:1318).

Pastoral communities in different regions use similar techniques of feltmaking, but their craft differs most prominently in the type of wool and the design and layering of felt patterns. Patterning rolled wool on a semi-prepared base, as presented in the case study, is characteristic of Kazakh and Kirghiz methods (Eiland 2007:277). Mongol felts are usually white and sewn to a backing of brown felt. The monochrome pattern is stitched to the felt with slight bulges in between the stitching to resist stretching (Batchuluun 2003:Figure 7; Eiland 2007:277). Color patterns are not felted to the base but secured with backstitching or chain stitching. Turkmen felts are composed of a white layer, a brown base layer, and colored patterns beaten and stitched into it (Laufer 1930:13); more elaborate pieces are appliquéd with wool strands (Burkett 1977:114; Eiland 2007:275; Raina 1993:84).

The mechanics and instruments of felt-making in the case study do not differ from those in other pastoral cultures. Beating wool with sticks to loosen the fleece and filter out excess dirt and matted fibers is practiced among Mongol, Kirghiz, Kazakh, and Turkish felt-makers (Bunn 2010; Laufer 1930:13, 16). Across Central Asia, specialized craftsmen use an instrument known as the carding bow (Eiland 2007:278-279; Róna-tas 1963:212). Though a less efficient and popular method, it produces finer wool. The rolling mat may be made of sedge (Eiland 2007:275) or hide (Raina 1993:83).

\section{Conclusion}

Through a field documentation of two traditional domestic crafts-the making of milk products and felt-this preliminary study assesses the vitality of techniques of production once indispensable to pastoral subsistence in Xinjiang today amid state-controlled sedentarization programs, urbanization, and industrialization. As much as the present Chinese discourse has romanticized social and economic improvements that remodeling traditional pastoral nomadism would bring, the campaign suffered setbacks, and the future of pastoral crafts remains one disconcerting and under-examined aspect. The study addresses this critical oversight in three regards-lineage, prevalence, and practice. 
I observe that while domestic production of milk products remains prevalent, the opportunity to explore its economic potential as authentic artisanal foods is compromised by "Green Food" banners that large corporations use to market industrially processed dairy products made from milk sourced from pastoralist shareholders. Meanwhile, felt-making is no longer the utilitarian craft once vital to pastoral livelihood and artisanal felt articles are assimilated into urban living as a token of ethnic heritage and pigeonholed by state administration as a cultural relic. The prospect of conserving it in ways that are gainful for traditional practitioners thus remains untapped by present reforms.

I question the socioeconomic implications of foregoing these important techniques of developing animal secondary products-milk and woolconsidering the goals of the present pastoral reforms. I argue that, because they constitute long-established traditions vital to pastoral livelihood, harnessing these specialized skills of production as valuable TEK would complement state goals of bettering the lives of resettled pastoralists and vitalizing new urbanized areas. As this study is only based on two cases, I leave for future investigation a more systematic survey of these and other pastoral crafts and the research of possible resolutions. This study and future research should support a more holistic approach to pastoral reforms by highlighting the pertinence of addressing the materiality of pastoral crafts as people, the environment, and systems of production mediate the thresholds for sustainable change.

\section{Acknowledgments}

The author would like to thank the practitioners and their families for their generous hospitality and the opportunity to observe and learn about their crafts. The assistance of local interpreters, Bieke Nu'erlan and Axibate, was indispensable to the field research. The author is grateful to Christine Martens for lending her expert insights into felt-making, to Christopher Atwood for his instructive comments, and to the editors and anonymous reviewers for their valuable input. The study was conducted in tandem with archaeological fieldwork supported by the ACLS/Henry Luce Foundation and the Penn Museum as part of dissertation research. Any errors found herein are the author's alone.

\section{References Cited}

Abuduresule, Y., G. Liu, and W. Li. 2004. The 2002 Excavation Report of Xiaohe Cemetery. Research of China's Frontier Archaeology 3:338409.

Atwood, C. P. 2004. Encyclopedia of Mongolia and the Mongol Empire. Facts on File Library of World History, New York.

Batchuluun, L. 2003. Felt Art of the Mongols. Institute for the Study of Arts and Culture, Mongolian University of Arts and Culture, Ulaanbaatar.

Benson, L., and I. Svanberg. 1998. China's Last Nomads: The History and Culture of China's
Kazaks. Studies on Modern China. M.E. Sharpe, Armonk, NY.

Bogaty, H., A. M. Sookne, and M. Harris. 1951. The Felting of Wool as Related to the Elastic and Swelling Behavior of the Fiber. Textile Research Journal 21:822-826.

Bohm, L. 1945. Mechanism of Felting of Wool Fibres. Nature 155:547-548.

Bunn, S. 2010. Nomadic Felts. Artistic Traditions in World Series. The British Museum Press, London.

Burkett, M. E. 1977. An Early Date for the Origin of Felt. Anatolian Studies 27:111-115. 
Cerny, A. 2008. In Search of Greener Pastures: Sustainable Development for Kazak Pastoralists in Xinjiang, China. Doctoral Dissertation, Department of Geography, University of Washington, Seattle, WA. Available from ProQuest Dissertations and Theses database (UMI No. 3318166).

Degen, A. A. 2007. Sheep and Goat Milk in Pastoral Societies. Small Ruminant Research 68:7-19.

Di Cosmo, N. 1998. Qing Colonial Administration in Inner Asia. The International History Review 20:287-309.

Dong, S. K., L. Wen, S. L. Liu, X. F. Zhang, J. P. Lassoie, S. L. Yi, X. Y. Li, J. P. Li; and Y. Y. Li. 2011. Vulnerability of Worldwide Pastoralism to Global Changes and Interdisciplinary Strategies for Sustainable Pastoralism. Ecology and Society 16:10.

Eiland, M. L., III. 2007. Felting between East and West. Visual Anthropology 20:263-283.

Evershed, R. P., S. Payne, A. G. Sherratt, M. S. Copley, J. Coolidge, D. Urem-Kotsu, K. Kotsakis, M. Özdoğan, A. E. Özdoğan, O. Nieuwenhuyse, P. M. M. G. Akkermans, D. Bailey, R-R. Andeescu, S. Campbell, S. Farid, I. Hodder, N. Yalman, M. Özbaşaran, E. Bıçakcı, Y. Garfinkel, T. Levy, and M. M. Burton. 2008. Earliest Date for Milk Use in the Near East and Southeastern Europe Linked to Cattle Herding. Nature 455:528-531.

Farahani, G., H. Ezzatpanah, and S. Abbasi. 2014. Characterization of Siahmazgi Cheese, An Iranian Ewe's Milk Variety: Assessment of Physico-Chemical, Textural and Rheological Specifications during Ripening. LWT Food Science and Technology 58:335-342.

Feng, R., and Aimaiti. 2008. Changes in the Material Life and Folklore Culture of Kazakhs in Xinjiang based on the Survey of Sarbulak Village in Huocheng County, Ili Prefecture. Journal of Northwest University for Nationalities (Philosophy and Social Science edition). 3:110-118.

Feng, L., and Y. Chu. 2010. A Brief Discussion of the Problems and Countermeasures of the Sedentarization of Pastoralists in Xinjiang. Bridge of Century 9:63-4.

Fernandez-Gimenez, M. E. 2000. The Role of Mongolian Nomadic Pastoralists' Ecological Knowledge in Rangeland Management. Ecological Applications 10:1318-1326.

Gervers, M., and W. A. Schlepp. 1997. Felt and "Tent Carts" in "The Secret History of the Mongols". Journal of the Royal Asiatic Society, Third Series 7:93-116.
Hirata, N. 2003. The Dualism of the Milk Cultural Sphere in the Arid Areas of Eurasia. The Archaeology of West Asia 4:21-30.

Humphrey, C., and D. Sneath. 1996. Pastoralism and Institutional Change in Inner Asia: Comparative Perspectives from the MECCIA Research Project. Overseas Development Institute Research Reports and Studies. London, UK.

Ishii, S., and K. Samejima. 2006. Products Made from Camel's Milk by Mongolian Nomads. Milk Science 55:79-84.

Laufer, B. 1930. The Early History of Felt. American Anthropologist, New Series 32:1-18.

Lei, Z. 2011. A Study on the Effects of and Improvements on the Settlement Policy of Pastoral Ethnic Minorities based on the Investigation of Two Settlements in Bortala Mongol Autonomous Prefecture. Journal of South-Central University for Nationalities (Humanities and Social Sciences) 31:1-6.

Liao, C., C. Barrett, and K-A. Kassam. 2015. Does Diversification Improve Livelihoods? Pastoral Households in Xinjiang, China. Development and Change 46:1302-1330.

Liao, C., S. J. Morreale, K-A. S. Kassam, P. J. Sullivan, and D. Fei. 2014. Following the Green: Coupled Pastoral Migration and Vegetation Dynamics in the Altay and Tianshan Mountains of Xinjiang, China. Applied Geography 46:61-70.

Lu, D. 2010. The Current Situation and Future of the Dairy Industry in Xinjiang. China Dairy Industry 38:31-34.

Luo, F. 2012. Liquor Still and Milk-wine Distilling Technology in the Mongol-Yuan Period. In Chinese Scholars on Inner Asia, edited by X. Luo, pp. 487-518. Sinor Research Institute for Inner Asian Studies Indiana University, Bloomington, Indiana.

Ma, L. 2008. Moderate Sedentarization of Pastoralists in Xinjiang and Resolutions. Xinjiang Agricultural Sciences 45:1196-1201.

Martin, M. 1980. Pastoral Production: Milk and Firewood in the Ecology of Turan. Expedition 22:24-25.

Menkart, J., and J. B. Speakman. 1947. Felting of Animal Fibres. Nature 159:640.

Minzhigdorj, B., and B. Erdenebaatar. 1993. Why Mongolians Say Sheep Herders are Lucky. Nomadic Peoples 33 (Pastoralism in Mongolia):47-49.

Montell, G. 1937. Distilling in Mongolia. Ethnos 2:321-332.

Mullins, W. G. 2009. Felt. Berg, Oxford and New York. 
Pannell, C. W., and L. J. C. Ma. 1997. Urban Transition and Interstate Relations in a Dynamic Post-Soviet Borderland: The Xinjiang Uygur Autonomous Region of China. Post-Soviet Geography and Economics 38:206229.

Population Census Office, the State Council Department of Population and Employment Statistics National Bureau of Statistics. 2012. Tabulation on the 2010 Population Census of the People's Republic of China (3 volumes). China Statistics Press, Beijing.

Raina, R. 1993. Frozen in Time: Ancient Skills of the Mongols. India International Centre Quarterly 20:79-94.

Róna-tas, A. 1963. Felt-making in Mongolia. Acta Academiae Scientiarum Hungaricae 16:199-215.

Sayilan, M. 2011. A Brief Discussion of the Inevitability and the Developmental Trends of the Sedentarization of Pastoralists in Xinjiang. Knowledge Economy 14:71.

Serruys, H. 1974. Kumiss Ceremonies and Horse Races: Three Mongolian Texts. Otto Harrassowitz, Wiesbaden.

Shepherd, R. J., and L. Yu. 2013. Heritage Management, Tourism, and Governance in China. Managing the Past to Serve the Present. Springer-Verlag, New York.

Shinjilt. 2010. Introduction: Remote Regions of Western China and "Ecological Migration". In Ecological Migration: Environmental Policy in China, edited by M. Nakao, Y. Konagaya, and S. Chimedyn, pp. 11-39. Peter Lang, Bern; New York.

Soni, S. K. 2010. Mongols of Xinjiang. Himalayan and Central Asian Studies 14:79-93.

State Administration of Cultural Heritage. 2008. Interim Policies on the Protection and Management of National Intangible Cultural Heritage. Available at: http://www.sach. gov.cn/art/2008/10/14/art_1035_6953.html. Accessed on October 13, 2016.

Stigter, D. 1971. On a Correlation between the Surface Chemistry and the Felting Behavior of Wool. Journal of the American Oil Chemists' Society 48:340-343.

The Standing Committee of the Ninth National People's Congress of the People's Republic of China. 2002. Grassland Law of the People's Republic of China (Order of the President of the Republic of China No. 82). Available at: http: / / english1.english.gov.cn/laws/200510/09/content_75387.htm. Accessed on September 15, 2016.
Tracy, M. 2013. Pasteurizing China's Grasslands and Sealing in Terroir. American Anthropologist 115:437-451.

Trever, K. V. 1932. Excavations in Northern Mongolia, 1924-1925. Leningrad.

Uchida, K., M. Hirata, H. Motoshima, T. Urashima, and I. Arai. 2007. Microbiota of "Airag", "Tarag" and Other Kinds of Fermented Dairy Products from Nomad in Mongolia. Animal Science 78:650-658.

Wolverton, S., J M. Nolan, and M. Fry. 2016. Political Ecology and Ethnobiology. In Introduction to Ethnobiology, edited by U. P. Albuquerque and R. Alves, pp. 75-82. Springer International Publishing, Cham, Switzerland.

Xu, H., W. Liu, Q. Gesudu, Z. Sun, J. Zhang, Z. Guo, Y. Zheng, Q. Hou, J. Yu, Y. Qing, L-Y Kwok, B. Menhea, and H. Zhang. 2014. Assessment of the Bacterial and Fungal Diversity in Home-Made Yoghurts of Xinjiang, China by Pyrosequencing. Journal of the Science of Food and Agriculture 95:2007-2015.

Xun, L. and Z. M. Bao. 2008. Government, Market and Households in the Ecological Relocation Process: A Sociological Analysis of Ecological Relocation in S Banner. Social Sciences in China 29:113-128

Yang, Y., A. Shevchenko, A. Knaust, I. Abuduresule, W. Li, X. Hu, C. Wang, and A. Shevchenko. 2014. Proteomics Evidence for Kefir Dairy in Early Bronze Age China. Journal of Archaeological Science 45:178-186.

Yeh, E. T. 2009. Greening Western China: A Critical View. Geoforum 40:884-894.

Yessengaliyeva, A. M., and S. B. Kozhirova. 2016. Xinjiang Factor in Kazakhstan-China Relations. In Xinjiang- China's Northwest Frontier, edited by K. Warikoo, pp. 120-128. Routledge, Oxon; New York.

Zeder, M. A., and B. Hesse. 2000. The Initial Domestication of Goats (Capra hircus) in the Zagros Mountains 10,000 Years Ago. Science 287:2254-2257.

Zheng, J., and T. Chen. 2005. An Analysis of the Market Competitiveness of Fine Wool from Xinjiang. Xinjiang Agricultural Sciences 42:434-437.

Zhou, Y. 1994. (Kazakh Milk Consumption Culture and Practices). Journal of Ili Normal University 3:39-44.

Zhou, Y. 2006. On the Inheritance and Development of Traditional Kazakh Folk Skills with Hu'agen Village in the Kazakh Township of Ashili as a Case Study. Journal of Xinjiang University 34:85-89. 